\title{
LOCAL CUISINE AND TOURISTS EXPERIENCE IN BALI THROUGH SOCIAL MEDIA PRACTICES
}

\author{
Komang Ratih Tunjungsari, Dika Pranadwipa Koeswiryono. \\ The International Bali Institute of Tourism \\ ratih.tunjung@stpbi.ac.id
}

\begin{abstract}
Balinese local cuisine has enriched the culinary dictionary for tourists who want to experience the culture and heritage of Bali. Popularity of tourist destination nowadays can be defined by the popularity of the local cuisine as the tourist image brand and image. The purpose of this article was to describe the involvement of local cuisine gradually in tourist experience quality as the integral part of food tourism in Bali. It aimed to determine the tourists' experience in seeking local cuisine and the perception of Balinese local cuisine, specifically nasi campur Bali and ayam betutu in creating food tourism in Bali. In order to develop the exploratory study, the author used exploratory descriptive methodology in this small-scale research. This study was just a beginning and an introduction to the food tourism in Bali although the practices had been experienced long ago before it was written in hospitality literature like nowadays.
\end{abstract}

Keywords: local cuisine, holiday experience, food tourism, social media

\section{INTRODUCTION}

Food and tourism are placed as one entity in the traveling experience. Kivela and Crotts (2015) said that our sensory have a main role in psychological and physiological in giving appreciation of food at the same time, experience the destination. As agreed and reported by the World Tourism Organisation (2012), the cuisine of the destination is one of the most important aspects to make a holiday experienced qualified in term of quality. Nicu and Nistoreany in Gheorghe, Tudorache, and Nistoreanu (2014), explain three basic consumptions as an integral part of tourist experiences such as, visiting places, attendance to different traditions and customs and lastly eat local cuisine. Moreover, studies reported by World Tourism Organisation in Gheorghe, Tudorache, and Nistoreanu (2014) shows over $88 \%$ of its members consider that gastronomy as a strategic element in defining destination brand and image.

Covarrubias in Pitanatri (2016) stated that the taste of local cuisine in Bali is quite hard to deal with their tongue when the first time he came to Bali even though he is used to eating chili in Mexico. However, after the first trial then he became familiar with the strange mix of spices. It can be assumed from the statement, that local cuisine in Bali is quite typical dishes for Western tourist who are not like a lot of spices in their plate. Meanwhile, Nasi Campur Bali in Ubud, namely Nasi Ayam Kedewatan Ibu Mangku turned out very popular since reviews on Tripadvisor become common (Pitanatri, 2016).

The development of the Internet also helps to evolve the local cuisine to be more known by Western and also domestic tourists. For example Babi Guling, or suckling pig cooked with traditional recipes and pour with spices, has been recognized through the television program brought by Antony Bourdin in his so- 
called series 'No Reservations'. Moreover, Babi Guling also put as one of the six dishes that is compulsory to try when traveling to Bali by Brown (2014) via CNN. This phenomenon is very common since authenticity of travel experience is inseparable from authentic cuisine from the destination. Nowadays travel channel in social media shows food as one of tourist experience to feel the culture of tourist destination. Not only on Youtube, but also other social media is growing to promote product and tourist destination.

Very few empirical studies are reported in the hospitality literature in confirming the relationship between gastronomy and tourism experience, even though many studies explore the factors that affect the tourist image toward destination. This study's objective to explore the areas of perceived image created by Balinese local cuisines such as nasi campur Bali (rice with mixed dishes), ayam betutu (Chicken Steam with special Balinese Spices), fried duck and babi guling (suckling pig) in representing food tourism in Bali. Specifically, the study aims to determine (a) if tourists seek the local cuisine in Bali to complete the holiday experiences and (b) if food tourism especially local cuisine in Bali manageable for tourists. The purpose of this research is to identify how local cuisine influences how tourists experience a destination and also the practices of social media nowadays.

\section{LITERATURE REVIEW}

\section{Tourist Experiences on Local Cuisine}

Despite the abundance exploration on tourist experiences on travel and accommodation, leisure on local cuisine does not seem to be equally investigated. Having local meal at a destination provides distinctive interaction between tourist and the local culture. Several researchers have also put forward their insight on vacation experience with local food. Murniati and Yooptech (2013) view that among the attractions offered by a tourist destination, experience on ethnic food contributes in forming the perception and this further destination image. It also serves as link between tourist and local community. Consuming local food is a part of the leisure experience, as it is often used to exhibit the cultural attraction by having the tourist try the authentic food in the destination.

Those who are to develop a culinary-based tourism industry are expected to take into account two concerns: the food and the serving. The first factor includes the food appearance and its ingredients. The second one involves a traditionally set eating atmosphere, as well as the ability to communicate with tourist in terms of explaining the food or the culture influence lying behind it (Ardabili, 2011). This implies that the food alone is not enough unless the producer communicates it to the society and travelers.

Some tourists, however, regard local food not as a leisure activity. It is therefore important to find ways to add value to memorable eating experience (Hjalager, 2002). The term gastronomy tourism by Ignatov and Smith in Wijaya (2014) is including the styles of food preparation and consumption within the social context. Moreover, cited in Wijaya (2014), Green and Dougherty define culinary tourism as enjoyment in memorable eating and drinking experiences, to connect with the local food system toward visitor experience. 


\section{Balinese Local Cuisine (Nasi campur Bali, Ayam Betutu, Babi Guling, and Bebek Betutu/Goreng)}

The well known Balinese food, among many, are Nasi Campur, Ayam Betutu, Babi Guling and Bebek Betutu. The strong spice may taste unusual to westerner's tongue, but little adjustment is all it takes to familiarize them toward travelers. Those who are in need of local food experience would visit several famous areas, such as Ubud. The village has long been a tourist hub where not only yoga but also local cuisine that attract tourist to crowd into. A study by Pitanatri (2016) mentions Ibu Mangku's Chicken Rice, Ibu Oka's Suckling Pig or Bebek Bengil as the leading restaurants serving Balinese food.

Ayam Betutu is one of Balinese local food that is widely known coming from the west part of Bali. It was originally purposed for religious activities, yet can nowadays be found among restaurant menu. It is the food's thick spices absorbing into the chicken flesh and its soft texture that characterize Ayam Betutu. The late Men Tempeh was the figure who has since 1978 brought this cuisine to fame. Kangkung vegetables, a tiny plate of sambal and another of fried beans are what Ayam Betutu served along with (Suardani, 2011). When it comes to rice, Nasi Campur (rice with mixed dish) is what usually Balinese would point to. Consisting of rice, sate lilit, urab and sambal matah, the spicy and savory nasi campur can be obtained in most towns in Bali. Recent modification in Nasi Campur includes eel as the substitute for chicken (Prastika, 2012).

In this mostly Moslem followers country, Babi Guling (suckling pig) has also interestingly gained significant enthusiast, especially in Bali. Babi guling which was once prepared for ceremonial purpose in Balinese tradition, has now become local food with economic commodity value (Budiarsa (2012). Pitanatri (2016) reports that Ibu Oka's Suckling Pig reaches popularity even among westerners. A mix of pork or chicken, young jackfruit, bean, young papaya and coconut are what people would refer to when mentioning Lawar. Similar to Babi guling and Ayam Betutu, Lawar is also involved when Balinese religious ceremonies take place and nowadays consumed as daily rice package for Balinese.

\section{Social Media Practices}

Usage of social media and Internet nowadays are becoming more popular, as especially the young now immerse themselves in virtual world. Euromonitor (2014) releases that among the most popular social media in Indonesia are Facebook and Twitter. The former engages up to 63 million users, whereas the later reach 29 million active accounts. Instagram and Path gained popularity among high-income urbanites. Apart from connecting users, social media are now employed as a means of marketing, be it accommodations, travel package or food.

Culinary products promotions through printed media such as magazine or news paper are now being rivaled by the ones spreading across social media and internet. What internet has, that the non-electronics lack, is the quick and almost borderless access. Filenius \& Kettunen (1998, in Vu 2013) highlight social media's effectiveness in catching up with changing trends, maintaining customer relationship and finding the right group if consumer. Its ability to deliver information at any time is another advantage in promoting food toward customers.

Similarly, Lee (2012) also points out the fast and cost-effective nature of food marketing via internet. He further adds that a traveler's desire is not merely 
the cuisine but also the atmosphere in which he enjoys the local and authentic experience. Nowadays, software such as Facebook or Twitter allow the customer to share their experience, be it in pictures, videos or text. Technologies like GPS, smartphones and cameras have even amplified the promotion.

\section{METHODOLOGY}

Data collection instruments or research instruments means the techniques or tools used to collect data such as observation, questionnaires, and interview (Fitzpatrick and McCarthy (2016). This study will use both of these two types of data collection, qualitative and quantitative in which will be specified below. Primary data can be achieved through several methods, such as sampling procedures, exploratory methods, survey methods and observation. While Saunders, Lewis and Tornhill (2012) explain the types of secondary data generally for examples; documentary (text and non-text), tabulated survey (censuses, continuous or regular surveys, ad hoc surveys), and multiple sources (snap shot and longitudinal).

In addition, after the gathered data analyzed, the result of the questionnaires will be described or it is known as descriptive statistics. Descriptive statistics will include calculation of means, standard deviations, and describes the results within the percentage and narration (Burns and Bush, 2003, p.434). The questionnaires will include the respondents demographic, and dimensions of food tourism and social media. Each variable utilizes Likert-type questions, and scored by the Likert scale as shown in Table 1 (Boone and Boone, 2012, p. 2). Besides, the author also prepared open question in the questionnaire with short answer for the question of social media. This study will use random sampling and already prepared filter question to plot the respondents who already experienced local cuisine and using social media. Furthermore, this author also uses interview with the foodies and food blogger that listed in Bali to add any acknowledgment about social media practices nowadays.

Table 1. Lykert scale

\begin{tabular}{|l|c|c|}
\hline Statement & Scale & Range \\
\hline Strongly agree & 5 & $253-300$ \\
\hline Agree & 4 & $205-252$ \\
\hline Neutral & 3 & $157-204$ \\
\hline Disagree & 2 & $109-156$ \\
\hline Strongly Disagree & 1 & $60-108$ \\
\hline
\end{tabular}

Using Likert Scale within 5 range from minimum score (1) until maximum score (5), authors using 60 respondents who came to Bali, try Balinese cuisine and using social media to seek information. Thus, the scale will be :

Maximum range : (5) x 60 (number of respondents) $=300$

Minimum range : (1) x 60 (number of respondents) $=60$

The interval : $\underline{300-60}=\underline{240}=\mathbf{4 8}$ 


\section{RESULTS}

The research focuses on what kind of social media that has been used by tourists to find information regarding local cuisine. Results in Table 2 shows the demography of the respondents that mostly from productive ages and mostly graduated or still studying in University or College since most of the occupation mentioned are students.

Table 2. Result from Demography and

\begin{tabular}{|c|c|c|}
\hline No. & Category & Results \\
\hline 1. & Gender & $\begin{array}{l}\text { Female }: 22 \\
\text { Male : } 37\end{array}$ \\
\hline 2. & Marital Status & $\begin{array}{l}\text { Single/divorce/widow : } \mathbf{5 1} \\
\text { Married : } 9\end{array}$ \\
\hline 3. & Latest Education & $\begin{array}{l}\text { College or University : } 49 \\
\text { Master : } 10 \\
\text { High School : } 1\end{array}$ \\
\hline 4. & Age & $\begin{array}{l}18-20 \text { yo }: 24 \\
21-29 \text { yo }: 22 \\
30-39 \text { yo }: 11 \\
40-49 \text { yo }: 3\end{array}$ \\
\hline 5. & Annual Income & $\begin{array}{l}\text { Less than US\$ } 5.000: 32 \\
\text { US\$ } 5.000-\$ 9.999: 13 \\
\text { US\$ } 10.000-\$ 14.999: 5 \\
\text { More than US\$ } 10.000: 6 \\
\text { Not yet worked }: 4\end{array}$ \\
\hline 6. & Type of Visitors & $\begin{array}{l}\text { Family : } 25 \\
\text { Group : } 2 \\
\text { Friends : } 19 \\
\text { Individual : } 6 \\
\text { Others : } 8\end{array}$ \\
\hline 7. & Number of visitors & $\begin{array}{l}\text { First time }: 10 \\
\text { Twice }: 5 \\
\text { Three times : } 4 \\
\text { More than three times }: 41\end{array}$ \\
\hline 8. & Occupation & $\begin{array}{l}\text { Owner : } 3 \\
\text { Manager/Executive : } 2 \\
\text { Professional/technical : } 13 \\
\text { Skilled worker : } 8 \\
\text { Unskilled worker : } 0 \\
\text { Farming/fishing/forestry : } 0 \\
\text { student : 32 } \\
\text { retired : } 2\end{array}$ \\
\hline 9. & Social media to find information & $\begin{array}{l}\text { Travel guide website }: 12 \\
\text { Social media }: 34 \\
\text { Guide Book }: 1 \\
\text { Application such as Zomato, Qraved } \\
\text { and Tripadvisor : } 11 \\
\text { Other : } 2\end{array}$ \\
\hline
\end{tabular}


From the question of what kind of dishes that the tourist's like the most, their answer will be variants.

Table 3. Results from Statement

\begin{tabular}{|c|l|c|c|c|c|c|c|}
\hline No. & \multicolumn{1}{|c|}{ Statement } & $\mathbf{1}$ & $\mathbf{2}$ & $\mathbf{3}$ & $\mathbf{4}$ & $\mathbf{5}$ & Total \\
\hline 1. & $\begin{array}{l}\text { Experiencing different culture at destination } \\
\text { when travel culture at a destination? }\end{array}$ & 8 & 1 & 9 & 18 & 24 & $\mathbf{2 1 3}$ \\
\hline 2. & $\begin{array}{l}\text { Experiencing food and culinary experience at } \\
\text { destination is important }\end{array}$ & 5 & 0 & 4 & 10 & 37 & $\mathbf{2 4 2}$ \\
\hline 3. & Description about local cuisine sampled in Bali & 7 & 2 & 10 & 22 & 19 & $\mathbf{1 7 9}$ \\
\hline 4. & $\begin{array}{l}\text { You feel have to experience Balinese culture by } \\
\text { dining in local restaurant }\end{array}$ & 2 & 3 & 10 & 35 & 10 & $\mathbf{2 2 8}$ \\
\hline 5. & $\begin{array}{l}\text { Before visiting Bali, you had read about Balinese } \\
\text { culinary }\end{array}$ & 8 & 7 & 14 & 22 & 9 & $\mathbf{1 9 7}$ \\
\hline 6. & Local cuisine in Bali & 6 & 1 & 12 & 23 & 18 & $\mathbf{2 2 6}$ \\
\hline 7. & Satisfaction with quality of local cuisine in Bali & 5 & 4 & 10 & 19 & 22 & $\mathbf{2 2 9}$ \\
\hline
\end{tabular}

From Table 3 regarding the results of statement, most of respondents agreed that experience different culture at destination and also experience food and culinary is important while traveling to some new place. Moreover, through table 3 above also shown that most of the respondents not choosing to rate the local cuisine in Bali since they are in neutral area. Even though, the respondents feel that local cuisine in Bali taste goods at the end and also satisfied with the local cuisine in Bali. Added by a food blogger based in Bali who used social media to share information about local cuisine and trending café and restaurants around Bali, 'Nomnom Bali', said the power of social media to share and ask any information about local cuisine for tourist who wants to experience the Balinese culture. Most of the users still dominantly derive from domestic markets and using social media to find trending food such as (pork dishes in Bali with rice and mixed dishes).

\section{DISCUSSION}

Social media and tourist experience has gained popularity since the rise of Internet that everybody can easily share pictures, and obtained information from pictures. Previous year, when there is no Internet, published book, journal or article can be the possible tool to share tourist experience. By social media, time and space can be shortened, and can be kept in a digital way that everybody can see, as long as user control the usage of social media to share picture of foods to inform their experience and also to seek information prior to their arrival in Bali. Local cuisine in Bali has ingredients of spices that most of the tourist satisfied with its taste. Moreover, searching information about local cuisine should be done before experiencing the local food as one of local culture product of Bali. 


\section{REFERENCES}

[1] Ardabili, Farzad Sattari. (2011). The Role of Food and Culinary Condition in Tourism Industry. Middle East Journal of Scientific Research. (Vol. 9, 6). P. 826-833.

[2] Budiarsa, Komang. 2012. Potensi Ternak Babi dalam Menyumbangkan Daging di Bali. Exposed in "Seminar Nasional Ternak Babi di Fak. Peternakan Unud 5 Agustus 2014. Diakses pada [http://erepo.unud.ac.id/7249/1/ID3_19581204198503100211081408854m akalah-babi-seminar-2014-edit---pdf.pdf]

[3] Burns, A.C and Bush, R.F. (2003). Marketing research applications (4 ${ }^{\text {th }}$ ed.). Hall: Pearson Prentice.

[4] Boone, H. N and Boone, D.A. (2012). Analyzing likert data. Journal of Extension 50 (2), 2TOT2, 1-5.

[5] Brown, Samantha. (2014). 6 Dishes every Bali visitor needs to try. $2^{\text {nd }}$ Oct 2016. http://edition.cnn.com/2014/09/10/travel/balinese-dishes-cnngo/

[6] Euromonitor. (2014). Consumer lifestyle in Indonesia. Passport International.

[7] Fitzpatrick, J. J. And Mccarthy, G. (2016). Nursing Concept Analysis: Applications to research and practice. New York: Springer.

[8] Gheorghe, Georgiča, Tudorache, Petronela, Nistoreanu, Puiu (2014). Gastronomic Tourism, A New Trend For Contemporary Tourism. Cactus Tourism Journal, Vol. 9 (1). pp. 12-21.

[9] Hjalager, Anne-Mette. (2002). Repairing Innovation Defectiveness in Tourism. Tourism Management, Vol. 23. pp. 465-474.

[10] Kivela, Jakša and Crotts, John C. (2015). Tourism and Gastronomy's Influence on How Tourists Experience a Destination. Journal of Hospitality and Tourism Research, Vol. 30 (3), Agusut 2006. pp. 354-377.

[11] Lee, W., Xiong, L., Hu, C. (2012). The effect of Facebook users' arousal and valenve on intention to go to festival: Applying an extension of the technology acceptance model. International Journal of Hospitality Management, 3 (2012), 819-827

[12] Murniati, Dewi Eka and Yoopetch, Chanin (2013). Food's Role in Deterioting the Destination Competitiveness: A case of Yogyakarta, Indonesia. Cited in [https://www.google.com/url? sa=t\&rct=j\&q=\&esrc=s\&source=web\&cd=1 \&ved=0ahUKEwjOkaf5oPrbAhVFbysKHXkRASAQFggqMAA\&url=http $\% 3 \mathrm{~A} \% 2 \mathrm{~F} \% 2 \mathrm{Fstaff}$.uny.ac.id\%2Fsites $\% 2 \mathrm{Fdefault} \% 2 \mathrm{Ffiles} \% 2 \mathrm{Fpenelitian}$ $\% 2$ Fdewi-eka-murniati-mm\%2F7-ictl-bangkok-dewi-ekamurniati.docx\&usg=AOvVaw21stYVaxog1gyAPIJbUdmL]

[13] Pitanatri, Putu Diah Sastri. 2016. Women'r Role in Promoting Ubud as Culinary Destination in Bali. Journal of Hospitality Management (Vol.4, 3). ).114-122

[14] Prastika, Vincensia Erita Hana. (2012). Pengembangan Masakah Khas Bali (Lawar, Nasi CAmpur, Klaudan dengan Bahan Belut). Universitas Negeri Yogyakarta.

[15] Saunders, M., Lewis, P., and Thornhill, A. (2012). Research methods for business students $\left(6^{\text {th }}\right.$ ed). England: Pearson. 
[16] Suardani, Made. 2011. Analisis Keputusan Pengunjung Membeli Ayam Betutu pada Rumah Makan Ayam Betutu Khas Gilimanuk di Tuban Bali. Denpasar: Universitas Udayana

[17] Wijaya, Serli. 2014. Encounters with Local Food: The Culinary Experiences of International Visitors in Indonesia. Doctoral Thesis is College of Business, Victoria University, Melbourne, Australia. [http://vuir.vu.edu.au/25865/1/Serli\%20Wijaya.pdf]

[18] World Tourism Organisation (2012). Global Report on Food Tourism : AM Reports Volume Four. Madrid. 